\title{
Cost calculations and competitive benchmarking: a case study: Xeikon N.V
}

Citation for published version (APA):

Verwaijen, R., Vergauwen, P. G. M. C., Rongen, P., Busser, K., \& Vossen, D. J. L. H. (2001). Cost calculations and competitive benchmarking: a case study: Xeikon N.V. METEOR, Maastricht University School of Business and Economics. METEOR Research Memorandum No. 027 https://doi.org/10.26481/umamet.2001027

Document status and date:

Published: 01/01/2001

DOI:

10.26481/umamet.2001027

Document Version:

Publisher's PDF, also known as Version of record

\section{Please check the document version of this publication:}

- A submitted manuscript is the version of the article upon submission and before peer-review. There can be important differences between the submitted version and the official published version of record.

People interested in the research are advised to contact the author for the final version of the publication, or visit the DOI to the publisher's website.

- The final author version and the galley proof are versions of the publication after peer review.

- The final published version features the final layout of the paper including the volume, issue and page numbers.

Link to publication

\footnotetext{
General rights rights.

- You may freely distribute the URL identifying the publication in the public portal. please follow below link for the End User Agreement:

www.umlib.nl/taverne-license

Take down policy

If you believe that this document breaches copyright please contact us at:

repository@maastrichtuniversity.nl

providing details and we will investigate your claim.
}

Copyright and moral rights for the publications made accessible in the public portal are retained by the authors and/or other copyright owners and it is a condition of accessing publications that users recognise and abide by the legal requirements associated with these

- Users may download and print one copy of any publication from the public portal for the purpose of private study or research.

- You may not further distribute the material or use it for any profit-making activity or commercial gain

If the publication is distributed under the terms of Article $25 \mathrm{fa}$ of the Dutch Copyright Act, indicated by the "Taverne" license above, 


\title{
Cost Calculations and Competitive Benchmarking: \\ A Case study: Xeikon N.V.
}

\author{
Dr. Philip G.M.C. Vergauwen
}

\begin{abstract}
Xeikon N.V. is a young NASDAQ-listed company in the digital colour printing market. First of all, the student is expected to step into the role of an independent expert advising Xeikon's CEO. Although it is already clear that digital colour printing is competitive mainly at relatively small order quantities, the student is expected to give more specific information about the quantities for which Xeikon equipment is competitive. This will require different kinds of break-even analysis. Furthermore, students should analyse cost data using a learning curve model. In doing so, they should address the limitations of the model, test the usefulness in this situation and recognize that learning is not the right term in this context. The investigations require the use of regression analysis.
\end{abstract}

(Note: a case solution can be obtained by simple request) 